\title{
Territories Under Siege: Risks of the Decimation of Indigenous and Quilombolas Peoples in the Context of COVID-19 in South Brazil
}

\author{
Maurício Polidoro $^{1}$ (D) - Francisco de Assis Mendonça ${ }^{2}$. Stela Nazareth Meneghel ${ }^{3}$ (D) - Alan Alves-Brito ${ }^{3}$. \\ Marcelo Gonçalves ${ }^{4} \cdot$ Fernanda Bairros $^{3} \cdot$ Daniel Canavese $^{3}$ (1)
}

Received: 6 June 2020 / Revised: 7 September 2020 / Accepted: 7 September 2020 / Published online: 16 September 2020

(C) W. Montague Cobb-NMA Health Institute 2020

\begin{abstract}
The current health, political, and environmental crisis ongoing in Brazil and the advances of the impacts of COVID-19 in traditional populations (as indigenous and quilombolas) are not yet prioritized in the scientific production about the novel coronavirus. We performed spatial correlation analysis to map the clusters and outliers of COVID-19 in South of Brazil to identify indigenous and quilombolas communities impacted right now in the pandemic. We show that communities located nearby metropolitan areas and mid-sized cities are the most impacted by the COVID-19 and the advance of the transmission to inner states may intensify the ongoing historical process of elimination of indigenous and quilombolas people. We call for a global response to the indigenous and quilombolas situation in Brazil, pointing to the need of more analysis in the country;
\end{abstract}

Keywords Quilombolas · Indigenous · COVID-19 · Brazil

\section{COVID-19: The Pandemic of Dissent}

The severe acute respiratory syndrome coronavirus 2 (SARSCoV-2) was declared a Public Health Emergency of International Concern on January 30, 2020, by the World Health Organization (WHO), and it was named the Novel Coronavirus COVID-19 on February 11. This pandemic has brought to light various impacts on a global scale [1], wherein some countries gained visibility for having the highest number of cases during the onset of the disease (China, Iran, and Italy) and were later replaced by other countries throughout its manifestation (e.g., Spain, USA, and Brazil), following its global dynamics. Coping strategies against the pandemic varied widely according to regional differences and intersectional

Maurício Polidoro

mauricio.polidoro@gmail.com

Francisco de Assis Mendonça

chico@ufpr.br

Stela Nazareth Meneghel

stelameneghel@gmail.com

Alan Alves-Brito

alves.brito.a@gmail.com

Marcelo Gonçalves

marcelogeo@yahoo.com.br inequities, despite the WHO guidelines for general actions against the disease. This is especially true regarding measures to prevent viral transmission given the lack of a vaccine or effective medical actions to control the disease.

In Brazil, the conflict between measures from the central government (denying the severity of the issue) and those from states and municipalities (following sanitary and epidemiological guidelines), in addition to the insufficient and poor medical and hospital structure to fight the disease, has made evident the extremely high vulnerability of the population, particularly of those suffering from intense social and spatial exclusion, e.g., the indigenous and quilombola peoples. On February 26th, the then Health Minister defined COVID-19 as another type of flu in the history of the country; in the same

\author{
Fernanda Bairros \\ fernandabairros@gmail.com \\ Daniel Canavese \\ daniel.canavese@gmail.com \\ 1 Federal Institute of Rio Grande do Sul, Porto Alegre, Brazil \\ 2 Federal University of Paraná, Curitiba, Brazil \\ 3 Federal University of Rio Grande do Sul, Porto Alegre, Brazil \\ 4 State University of Londrina, Londrina, Brazil
}


week, the Brazilian currency (BRL) plummeted to critical levels. In April 16th, with an accumulated figure of 1933 deaths and an aggravating political crisis, a new Health Minister took office and resigned in less than a month due to the President's insistence to amplify the use of hydroxychloroquine, which showed little efficacy and severe side effects under clinical trials $[2,3]$.

Amidst the magnitude of this unprecedented public health crisis in Latin America, following the continuous dismantling and weakening of the Brazilian Public Health System (the Sistema Único de Saúde, SUS), Brazil has also become the scenario of political and social conflicts. Besides changes of Health and Justice Ministers, a meeting of State Ministers from April 22nd (when the death count was nearing the 3 thousand mark) was made public after an order by the Federal Supreme Court in response to accusations that the President had been meddling in the Brazilian judiciary police. In this meeting, the Environment Minister, who had already gained international notoriety due to his negligent watch over the Amazon [4], stated the moment should be used to pass more flexible environmental protection laws - i.e., for occupying indigenous land and weakening the surveillance and prosecution of violations - since the media was focused on covering the pandemic. In this context, violations of indigenous rights and traditions have taken on new proportions, such as the case of Yanomami babies in northern Brazil who were buried without their mothers' knowledge [5] and the distribution of chloroquine pills by the Brazilian Army in isolated indigenous territories [6].

This context is presented above via examples and simplifications of episodes that led to the widespread crisis currently faced by the largest economy of Latin America, and it directly affects original peoples, namely, the indigenous and quilombola communities. After the rights ensured by the Constitution of 1988, which provided guidelines for guaranteeing land titles to indigenous and quilombola peoples during the democratic governments following the military dictatorship (1989-2016), as well as the Health Equity Policies [7] which foreshadowed the SUS, indigenous and quilombola peoples have been living under an extremely vulnerable situation in the current political context of the pandemic. In this text, we present the evidence available regarding the occurrence of COVID-19 in indigenous and quilombola territories in South Brazil (i.e., the states of Paraná, Santa Catarina, and Rio Grande do Sul), seeking to alert the scientific community and the international society as means to revert this current trend of decimating Brazilian original peoples.

\section{Indigenous and quilombola Peoples in Brazil: Historical Disparities}

The root and effects of colonialism have been welldocumented in seminal works $[8,9]$. Especially in Latin
American and the Caribbean, the colonial enterprise which enabled the development of the capitalist economy was forged under the social classification of "race," contributing to what Peruvian sociologist Anibal Quijano [10] considers the current pattern of world power, engendered on the coloniality of power, wherein race and its intersections of class, gender, sexual orientation, disabilities, and geographical origin act as the basis of a universal social classification standard grounded on economic and social exploration.

During the colonial period (1500-1889), Brazil received, until 1850, approximately 3,143,903 million Africans from Western-Central Africa and Southeast Africa, from the Indian Ocean Islands and St. Helena Island. Out of this total, 4.2\% landed on the Amazon, $38.7 \%$ on Bahia, $12.1 \%$ on Pernambuco, and $44.2 \%$ on Southeast Brazil $[11,12]$. Regarding the indigenous people, according to indigenous leader Dinamam Jurum Tuxá of Brazil's Indigenous People Articulation [13], from the colonial regime until the 1970s, the Brazilian indigenous population was reduced from 5 million to approximately 450 thousand people, comprising 305 peoples, 274 languages. Exactly 174 peoples currently live in voluntary isolation in various parts of the country. Basic rights were only ensured in 1988, after the last military dictatorship and the promulgation of the Federal Constitution. This included the right to health (the creation of the SUS) and the positive recognition of the indigenous population and their specificities regarding education, cultural, and social and cultural organization. Despite being guaranteed by the Law and present on maps, the demarcation of indigenous lands is still subjected to internal conflicts [14-16], regional quarrels [17-19], and legal and historical disputes $[16,19,20]$ surrounding specific governmental policies that can effectively ensure full equity.

Accordingly, the 1988 Constitution granted quilombola communities the right to definitive ownership of their lands, stating the importance of historical lands and stepping away from the understanding of the Portuguese Ultramarine Council (1741), which considered quilombos as groups of fugitive slaves that presented risks to the colonial order until 1889 [21-23]. Therefore, it took the Brazilian State over 100 years to recognize a share of these peoples, herein considered original peoples. Some aspects of the historical process of invisibilizing Brazilian indigenous and quilombola peoples (the later are not included in the census) are the irregular surveys and the various techniques employed to understand the characteristics of this population, according to how "race" and "color" are understood. For example, indigenous peoples were only included in the demographic census in 1872 (under the term "caboclas") but were not included in the years 1900,1920,1940,1950, and 1960, returning only in 1991 under the classification of "indigenous" for the "race/ color" category [24].

South Brazil, the main territory discussed in this text, is commonly considered the "European" part of the country 
due to its subtropical climate - in contrast to the predominant tropical climate - and its historical process of European and Asian immigration (the latter especially in the Paraná state) motivated by successive governments (from the colonial period to the Republic). Since the end of the nineteenth century, governments have employed various legal resources to stimulate European settlers to come to Brazil and replace African and indigenous forced laborers. This movement was based on racist theories used to justify slavery, aimed at whitening the population. It defined Brazilian miscegenation as "racial degeneration" and a hindrance to the development of the "nation" $[25,26]$.

Keeping a large part of its population in poverty and excluding it from having basic rights and essential assets led Brazil to be extremely unequal and polarized, with a richer, white, Central-Southern region, and a poorer, colored, Northern-Northeastern region, as shown on Tables 1 and 2.

Tables 1 and 2 show the differences in the Brazilian population landscape, where southern states, especially Rio Grande do Sul state and Santa Catarina state, have a predominantly white population with better indicators than the national average in regard to life expectancy at birth, child mortality rate, and percentage of people living in extreme poverty. For example, whereas in the Northeast region people in extreme poverty represent $14.9 \%$ of the total population, in the South region they are only $1.6 \%$; for the Santa Catarina state, they are below the regional average, with $1.0 \%$. The overt regional disparities that show a white South with better indicators hide the extreme vulnerabilities of its non-white population, especially indigenous and Black people, that face the pressures of social and racial divisions arising from existing diverse spatial configurations [29]. It is also important to remember that despite northern Brazil holding the highest percentage of indigenous (1.9\% in comparison to the national average of $0.4 \%$ ) and mixed-race people $(66.8 \%$ in comparison to the national average of $43.1 \%$ ) while also encompassing the Amazon, the remaining original peoples (indigenous and quilombola) are distributed throughout the national territory (as shown on the map on Fig. 1).

\section{Indigenous and Quilombola Peoples in Brazil: Public Policies}

The 1988 Constitution defined health as a duty of the Brazilian State. The perspective of implementing a sole universal national health system, SUS, finally contemplated the indigenous and quilombola populations after centuries of exclusion [30]. The quality of life of these populations has been continuously vulnerable $[31,32]$ due to the inequities caused by race and gender intersections [33-36]. In Brazil, the quilombola [37] and indigenous populations [38] constantly face health violations, as denounced by scientific researches [39-42].

Public health policies geared towards the indigenous and quilombola populations have been promoted in the first decade of this century in consonance with the third National Plan for Human Rights, and complying to the Brazilian State alignment during the Durban Review Conference and its protagonism in leading the Global South in the United Nations [43]. This was the result of an unprecedented stance against the myth of racial democracy in Brazilian history, which had negated and invisibilized structural racism and the violence perpetrated against the Black and indigenous populations [44, 45].

The National Indigenous Health Policy from 2002 [46] was an important state response to its indigenous population and their specific demands. This document served as the basis for

Table 1 Population residing in selected geographical units per race/color, 2010

\begin{tabular}{|c|c|c|c|c|c|c|c|c|c|c|}
\hline \multirow[t]{3}{*}{ Scale } & \multicolumn{10}{|l|}{ Race/color } \\
\hline & \multicolumn{2}{|l|}{ Caucasian } & \multicolumn{2}{|l|}{ Black* } & \multicolumn{2}{|l|}{ Asian } & \multicolumn{2}{|l|}{ Mixed** } & \multicolumn{2}{|c|}{ Indigenous } \\
\hline & $\mathrm{n}$ & $\%$ & $\mathrm{~N}$ & $\%$ & $\mathrm{n}$ & $\%$ & $\mathrm{n}$ & $\%$ & $\mathrm{n}$ & $\%$ \\
\hline Brazil & $91,051,646$ & 47.7 & $14,517,961$ & 7.6 & $2,084,288$ & 1.0 & $82,277,333$ & 43.1 & 817,963 & 0.4 \\
\hline North & $3,720,168$ & 23.4 & $1,053,053$ & 6.6 & 173,509 & 1.0 & $10,611,342$ & 66.8 & 305,873 & 1.9 \\
\hline Northeast & $15,627,710$ & 29.4 & $5,058,802$ & 9.5 & 631,009 & 1.1 & $31,554,475$ & 59.4 & 208,691 & 0.3 \\
\hline Southeast & $44,330,981$ & 55.1 & $6,356,320$ & 7.9 & 890,267 & 1.1 & $28,684,715$ & 35.6 & 97,960 & 0.1 \\
\hline South & $21,490,997$ & 78.4 & $1,109,810$ & 4.0 & 184,904 & 0.6 & $4,525,979$ & 16.5 & 74,945 & 0.2 \\
\hline Midwest & $5,881,790$ & 41.8 & 939,976 & 6.6 & 204,599 & 1.4 & $6,900,822$ & 49.0 & 130,494 & 0.9 \\
\hline Paraná State & $7,344,122$ & 70.3 & 330,830 & 3.1 & 123,205 & 1.1 & $2,620,378$ & 25.0 & 25,915 & 0.2 \\
\hline Santa Catarina State & $5,246,868$ & 83.97 & 183,857 & 2.94 & 26,017 & 0.42 & 775,558 & 12.4 & 16,041 & 0.2 \\
\hline Rio Grande do Sul State & $8,900,007$ & 83.22 & 595,123 & 5.57 & 35,682 & 0.33 & $1,130,043$ & 10.5 & 32,989 & 0.3 \\
\hline
\end{tabular}

*preto; **pardo. Source: Brazilian Institute of Geography and Statistics [27] 
Table 2 Information on health conditions in selected geographical units, 2010

Fig. 1 Indigenous special health districts (coverage area)

\begin{tabular}{llll}
\hline Scale & $\begin{array}{l}\text { Life expectancy } \\
\text { at birth (2010) }\end{array}$ & $\begin{array}{l}\text { Child mortality } \\
\text { rate (2010) }\end{array}$ & $\begin{array}{l}\text { Percent of people } \\
\text { in extreme poverty (2010) }\end{array}$ \\
\hline Brazil & 74.4 & 16.7 & 6.6 \\
North & 72.2 & 18.4 & 12.8 \\
Northeast & 71.7 & 22.7 & 14.9 \\
Southeast & 75.2 & 14.3 & 2.3 \\
South & 75.5 & 12.3 & 1.6 \\
Midwest & 75.2 & 15.7 & 2.8 \\
Paraná state & 74.8 & 13.0 & 1.9 \\
Santa Catarina state & 76.6 & 11.5 & 1.0 \\
Rio Grande do Sul state & 75.3 & 12.3 & 1.9 \\
\hline
\end{tabular}

Source: Brazilian Institute of Geography and Statistics [28]

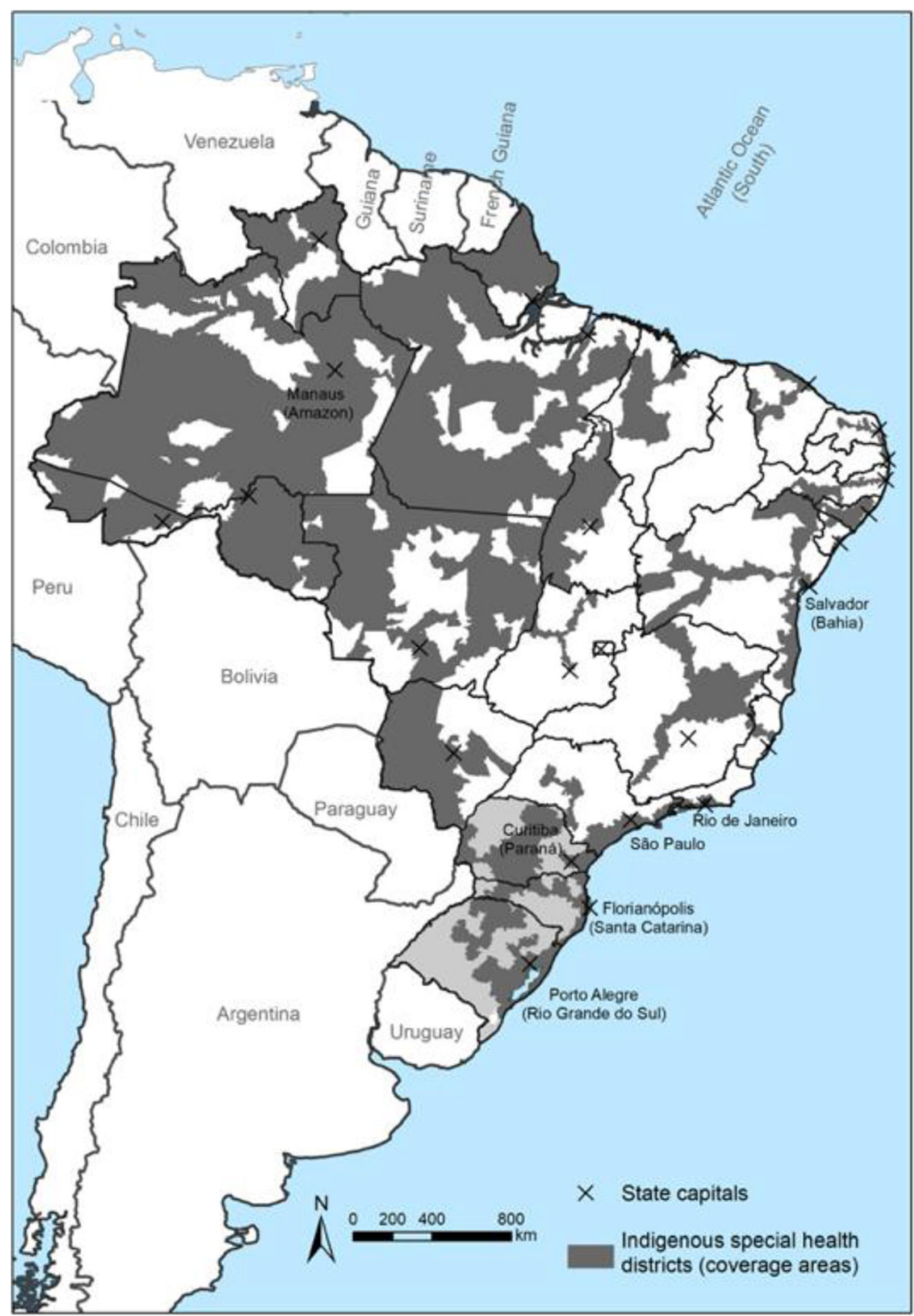


a health subsystem rooted in a geographical view of organizing health actions - the indigenous special health districts (shown in Fig. 1). This basic unit is defined as a geographical, populational, administrative, and dynamic ethnic and cultural space with no direct relation to the borders of states and municipalities where indigenous lands are located [47]. This perspective finds epistemological consonance in the knowledge of these peoples, given that indigenous territories are spaces where rulings are based not only on hegemonic value but also on ancestral and spiritual values.

Accordingly, the Ministry of Health also includes a special department for indigenous health. The data on the indigenous population is part of an information system for indigenous health care [48]. Despite this data fragmentation, these subsystems and their operation have considered social and demographic specificities that were essential for the survival of these peoples, although criticisms about access to information intensified during the pandemic [49]. Current data by the Ministry of Health show there are 34 indigenous special health districts responsible for providing services to 760.350 indigenous people from 416 ethnicities, living in 6.238 villages. Figure 1 shows the coverage of health care to indigenous peoples around the country according to these health districts.

After the current President took office in January 2019, one of the first actions by the Ministry of Health, besides compromising the effect of equity policies through significant structural changes [50], was to extinct the special department for indigenous health, as well as the indigenous special health districts [51]. This hygienist and homogenizing view sought to incorporate indigenous care within the context of the general population; thus, not considering the historical inequities these peoples have suffered over the ascension of a discourse based on a so-called "universal Brazilian citizen," as mentioned by the Brazilian Education Minister during the tragic ministerial meeting of April 2020, in which he stated his hate for the "indigenous peoples" because there is only the "Brazilian people." Also, during 2019, the presidential decree was revoked during a hearing of the Senate Commission on Human Rights organized by the Brazil's Indigenous People Articulation.

In 2007, on National Black Awareness Day, the National Health Policy for the Black Population [52] was presented. One of its goals was to ensure wide access to health actions and services to the Black population, as well as to the population living in rural areas and forests, particularly the quilombola population. The quilombola and indigenous populations are also addressed by the National Health Policy for the Rural and Forest Populations [53]. In contrast to the indigenous population, the quilombola population does not have a specific subsystem, partly due to its heterogeneous spread over the national territory, including communities at state capitals and the metropolises of Porto Alegre (Rio Grande do Sul) and Florianópolis (Santa Catarina).

\section{Territories Under Siege: Risks of Decimation During the COVID-19 Pandemic}

Secondary data were used to elaborate the map of territories under siege, herein considered as the ones located on spatially autocorrelated clusters. The data regarding COVID-19 were extracted on June 1st and encompassed the accumulated number cases up to the last day of the last epidemiological week of May. The information is available at the Brazilian Ministry of Health website <https://covid.saude.gov.br/> and has been organized in tables according to municipality, state, and health region, while also aggregating data on the accumulated number of new cases and deaths. Information regarding sex, race/color, ethnicity, and age were not available. Spatial data on quilombola communities were extracted from the Palmares Foundation website <http:// www.palmares.gov.br/?page id $=37551>$, and data on indigenous lands and health districts were extracted from the National Indian Foundation (FUNAI) <http://www.funai.gov. br/index.php/shape $>$. Due to the bureaucratic process surrounding the recognition of quilombola and indigenous lands, this analysis encompassed not only certified lands but also communities under study, i.e., the ones who have filed for analysis by the State but are not yet recognized on technical documents issued by the relevant institutions (Palmares Foundation for the quilombola and the National Indian Foundation for the indigenous people) (Fig. 2) (Table 3).

The spatial exploratory analysis method was applied using a spatial autocorrelation test for accumulated cases of COVID-19. The Global Moran's I was used to measure spatial autocorrelation. This is a spatial analysis extension available for the ArcGIS da ESRI-Environmental Systems Research Institute software [54]. This index also tests if the connected areas show higher similarity regarding the studied measure in comparison to what is expected on a random pattern, varying from -1 to +1 . Therefore, the spatial autocorrelation degree can be quantified: a positive figure for direct correlation (above 0 ) and a negative figure for inverse correlation (below 0 ). The Moran Map was employed as a graphical device to view results. To achieve this, a significance assessment was performed on the Moran index value for each municipality by comparing it with the null hypothesis of non-existing spatial autocorrelation. The result is shown in Fig. 3.

Based on Fig. 3, the municipalities shown in gray (HighHigh) have a high accumulated number of COVID-19 cases and are surrounded by municipalities that also have high figures. Municipalities in light-gray (Low-Low) are municipalities with a low accumulated number of COVID-19 cases that are surrounded by municipalities in this same situation. Traced and dotted municipalities (High-Low and Low-High, respectively) are municipalities with a high accumulated number of COVID-19 cases near municipalities with a low number and municipalities with a low accumulated number of 
Fig. 2 Indigenous and quilombola territories and the coverage area of the indigenous special health districts

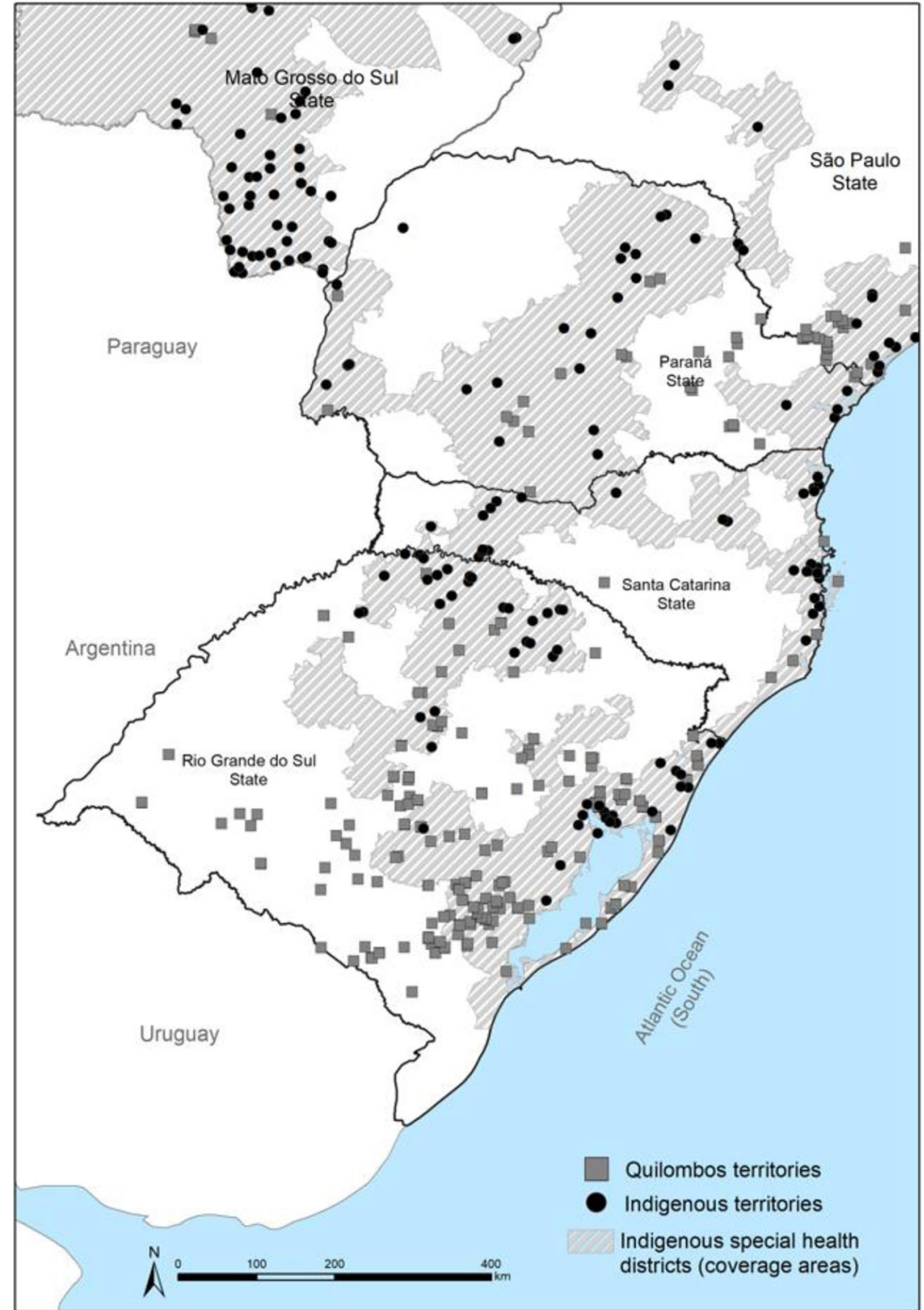

COVID-19 cases near municipalities with a high number, respectively. Municipalities in white are non-significant regions with a $p>0.05$, i.e., municipalities for which it is not possible to confirm whether spatial autocorrelation is present. In other words, they correspond to municipalities that show no correlation to the accumulated number of novel coronavirus cases in neighboring municipalities. It is also important to highlight the fact that despite some municipalities in the South region

Table 3 Concentration of clusters and outliers in indigenous communities of southern Brazilian states, 2020

\begin{tabular}{|c|c|c|c|c|c|c|c|c|c|}
\hline \multirow[t]{2}{*}{ Scale } & \multicolumn{9}{|c|}{ Indigenous communities } \\
\hline & $\mathrm{N}$ & N Cluster HH & $\%$ Cluster $\mathrm{HH}$ & N Outlier HL & $\%$ Outlier HL & N Outlier LH & \% Outlier LH & N Cluster LL & $\%$ Cluster LL \\
\hline Paraná State & 29 & 1 & 3.4 & 0 & 0 & 0 & 0.0 & 4 & 13.8 \\
\hline Santa Catarina State & 29 & 9 & 31.0 & 5 & 17.2 & 11 & 37.9 & 0 & 0 \\
\hline Rio Grande do Sul & 44 & 6 & 13.6 & 4 & 9.1 & 4 & 9.1 & 5 & 11.4 \\
\hline
\end{tabular}

Source: Authors, based on data by the Ministry of Health 
Fig. 3 Indigenous and quilombola territories and the Global Moran's I

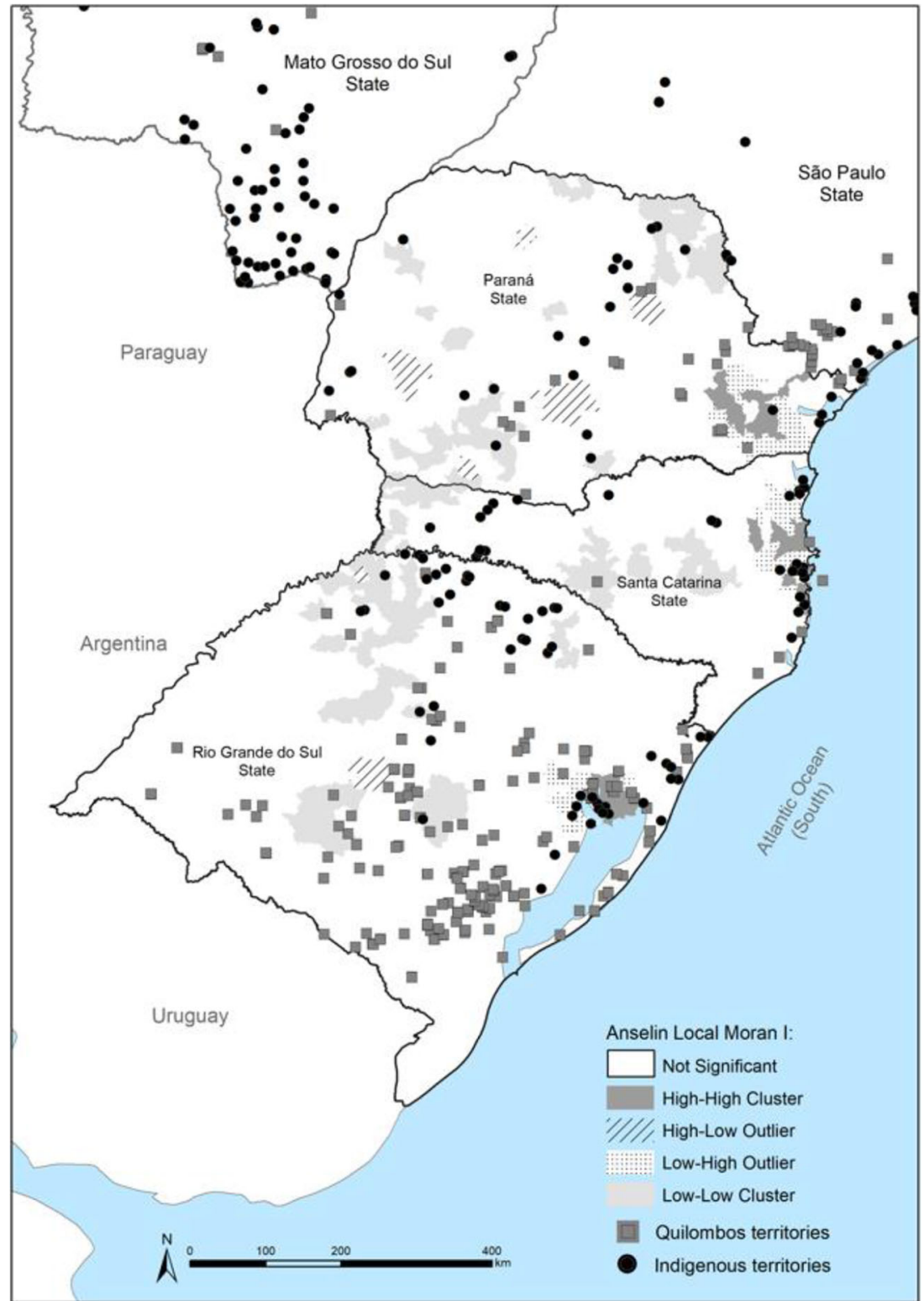

being classified as non-significant, this does not mean they should not be considered during the analysis. These municipalities may also have an accumulated number of COVID-19 cases but are not influenced by their neighboring municipalities; i.e., there is no spatial autocorrelation (Table 4).

The first aspect is that a large portion of indigenous and quilombola territories are centered around the clusters with the highest numbers of COVID-19 cases, in all three states. Amidst this critical scenario, numberless indigenous and quilombola peoples are settled around capitals and metropolitan areas. In the state of Santa Catarina, the High-High spatial characteristic extends from the state capital, Florianópolis, along the northern coast up to the border to the state of Paraná. In the state of Rio Grande do Sul, the situation can be considered critical due to the presence of four certified urban quilombos inside the state capital, Porto Alegre, as well as two quilombos undergoing the certification process. Porto Alegre (approximately 1.4 million inhabitants) is also the most racially segregated city in the country [55] which increases the urgency for help even in these territories.

The second noteworthy aspect is related to the concentration of indigenous and quilombola territories near High-Low clusters. This is the situation around most territories in the rural areas of the states of Paraná and Rio Grande do Sul. This outlook, therefore, gives the territory an aspect of being under siege; i.e., indigenous and quilombola peoples have at their borders a spatial scenario that increases their vulnerability and risk in the COVID-19 pandemic.

Notwithstanding the spatial characterization of novel coronavirus cases, the issues surrounding a permanent state of 
Table 4 Concentration of clusters and outliers in quilombola communities of southern Brazilian states, 2020

\begin{tabular}{|c|c|c|c|c|c|c|c|c|c|}
\hline \multirow[t]{2}{*}{ Scale } & \multicolumn{9}{|c|}{ Quilombola communities } \\
\hline & $\mathrm{N}$ & N Cluster HH & $\%$ Cluster HH & N Outlier HL & $\%$ Outlier HL & N Outlier LH & $\%$ Outlier LH & N Cluster LL & $\%$ Cluster LL \\
\hline Paraná & 34 & 0 & 0 & 0 & 0 & 4 & 11.8 & 0 & 0 \\
\hline Santa Catarina & 6 & 2 & 33.3 & 0 & 0 & 0 & 0 & 1 & 16.7 \\
\hline Rio Grande do Sul & 131 & 11 & 8.4 & 2 & 1.5 & 1 & 0.8 & 7 & 5.3 \\
\hline
\end{tabular}

Source: Authors, based on data by the Ministry of Health

siege become denser. The High-Low cluster consists predominantly of cities with low population, which for the Brazilian health system represents severe situations regarding socioenvironmental determinants in disease development. The first thing that should be mentioned is the low or nonexistent coverage of the basic sanitation network for indigenous and quilombola territories in these regions, according to the Brazilian Institute of Geography and Statistics, IBGE [56]. Moreover, there is no middle- or high-complexity care network available in their proximity. It is widely known that in the most affected places, there is a rapid increase in demand for hospital beds in Intensive Care Units (ICU) with assisted ventilation for people with severe acute respiratory syndrome. Therefore, indigenous and quilombola peoples face physical barriers when seeking access to health care during the pandemic, since these communities are far from the main driveways and intercity passenger transportation stops.

Another intriguing issue is the monitoring of epidemiological data about these peoples throughout the pandemic. The national emergency study performed by the Ministry of Health does not investigate traditional peoples [57]. Accordingly, national pandemic strategies have not included guidelines regarding these communities, particularly indigenous ones, which goes against international health recommendations [58]. However, recent scientific evidence shows that the so-called "ethnic minorities" have a higher risk of adverse outcomes related to infections by the novel coronavirus due to their situation of inequity [59-61]. It is known that the onset of the virus on Brazilian indigenous communities constitutes the catastrophic decimation of entire villages $[62,63]$. This is a recurring situation when discussing the measures adopted or neglected by the Brazilian government, which may result in the elimination of these vulnerable populations; this can effectively be considered a necropolitical action by the State [64].

Moreover, it is necessary to face the issues of underreporting and data quality regarding COVID-19 cases in the country. Mandatory reports of diseases, which allows for quilombola and indigenous peoples to be identified, have low-quality data in regard to race/color and ethnicity. The obligation to report health information systems is recent and has only been implemented for a little more than a decade [65]. Besides discrimination, there is also a lack of knowledge by health professionals regarding the self-identification of these people. To make matters worse, since the beginning of reports on the number of cases on the Ministry of Health website, it has not been possible to gain public access to the number of COVID-19 cases per race/color and ethnicity. This situation has led to the need for an initiative like the one by the National Coordination for the Articulation of Black, Rural, and Quilombola Communities, which has been performing a parallel survey to gather data to monitor the situation [66].

\section{The Urgency for Global Action}

The Brazilian government political stance in this global context has been proven to be peremptory, sectarian, and unconcerned with the repercussion of the pandemic to the population in general, which has gathered notoriety amongst the international scientific community [67]. Despite now being reported worldwide and received with bewilderment in the international community, the President's contempt is not new for indigenous and quilombola populations, but rather another facet of his hate speech towards the indigenous and quilombola peoples, which has been present since his 2018 electoral campaign [68].

There have been minor advances concerning the historical decimation process suffered by these populations, which has permeated colonial Brazil and been present until its current democracy. Such advances include the recognition of indigenous and quilombola lands and equity policies. However, these humble achievements are under dire risk in the current context of political turmoil surrounding the COVID-19 epidemic. As presented during this paper, which is part of a broader research endeavor surrounding the impact of COVID-19 on indigenous and quilombola communities, the spatial concentration of novel coronavirus cases poses a real immediate risk of decimating indigenous and quilombola communities in South Brazil, particularly in the states of Santa Catarina and Rio Grande do Sul, aside from accelerating the historical process of social and economic exclusion in central Paraná. For communities on central regions and the peripheries of state capitals (but also for ones under siege by clusters on inner state areas), health services are markedly precarious and tend to deteriorate the survival conditions these peoples already live in. 
The novel coronavirus pandemic presents new obstacles to maintaining the lives of Brazilian original peoples, who were already on an uncertain and worrisome path. Overcoming these obstacles is not solely an issue of providing the best possible coping strategies for this unprecedented sanitary crisis; it also depends on dealing with other historical crises, such as the legal recognition of the right to the land and the right to exist, going beyond the predatory economic model imposed by the current political and social framework. To surpass this challenge, an important step is mobilizing leaderships and widening the global reach of their voices and histories, as to prevent the tsunami [69]. looming on the Brazilian horizon which will, directly and indirectly, affect other countries of the Global South and the world.

Author Contributions The study conception and design, material preparation, data collection, and analysis were performed by Maurício Polidoro and Daniel Canavese. The first draft of the manuscript was written by Maurício Polidoro and Daniel Canavese. All authors commented on previous versions of the manuscript. All authors read and approved the final manuscript.

Data Availability All data used is free and unrestricted access.

\section{Compliance with Ethical Standards}

Conflict of Interest The authors declare that they have no conflict of interest.

Ethical Approval This article does not contain any studies with human participants or animals performed by any of the authors.

Informed Consent Not applicable.

Consent for Publication All authors consent the text for publication.

\section{References}

1. Nicola M, Alsafi Z, Sohrabi C, Kerwan A, al-Jabir A, Iosifidis C, et al. The socio-economic implications of the coronavirus pandemic (COVID-19): a review. Int J Surg. 2020;78:185-93. https://doi.org/ 10.1016/j.ijsu.2020.04.018.

2. Joshua Geleris J, Sun Y, Platt J, Zucker J, Baldwin M, Hripcsak G, et al. Observational study of hydroxychloroquine in hospitalized patients with Covid-19. N Engl J Med 2020 [online ahead of print].

3. Tang W, Cao Z, Han M, et al. Hydroxychloroquine in patients with mainly mild to moderate coronavirus disease 2019: open label, randomised controlled trial. BMJ. 2020;369:m1849.

4. Phillips D Studies add to alarm over deforestation in Brazil under Bolsonaro. The Guardian, 2020. Available from https://www. theguardian.com/environment/2020/may/28/studies-add-to-alarmover-deforestation-in-brazil-under-bolsonaro-covid-19. Accessed 29 May 2020

5. Costa E, Brasil K. Yanomami mothers fight for the right to bury their children during the COVID-19 pandemic in Brazil. Global Voices 2020. Available from https://globalvoices.org/2020/07/24/ yanomami-mothers-fight-for-the-right-to-bury-their-childrenduring-the-covid-19-pandemic-in-brazil/. Accessed 27 July 2020.
6. Biller D, Sousa M, Savarese M. Bolsonaro now 'poster boy' for dubious COVID-19 treatment. Wash Post 2020. Available from https://www.washingtonpost.com/world/the americas/bolsonaronow-the-poster-boy-for-dubious-covid-treatment/2020/07/09/ 6c892066-c199-11ea-8908-68a2b9eae9e0 story.html. Accessed 15 July 2020.

7. Souto KMB, Sena AGN, Pereira VOM, Santos LM. State and equity policies in health: participatory democracy? Saúde Debate. 2020;40:49-62.

8. Fanon F. Black skin, white masks. New York: Grove Press; 2008.

9. Memmi A, Sartre JP. The colonizer and the colonized. Expanded Edition. Beacon Press; 1991.

10. Quijano A. Coloniality of power and Eurocentrism in Latin America. Int Sociol. 2000;15(2):215-32.

11. Blight DW, Eltis D, Richardson D. Atlas of the transatlantic slave trade. New Haven: Yale University Press; 2010.

12. Estimates Database. "Voyages: the trans-Atlantic slave trade database." Slave Voyages. Emory, 2009. https://www.slavevoyages. org/. Accessed 29 May 2020.

13. Polidoro M, Canavese D, Tuxa DAJ. Podcast a.tua.ação - episódio 8 - os povos indígenas do Brasil e a pandemia da covid-19. 2020. Available from https://open.spotify.com/show/ 6MULopqysbuPgDEy6A9Eiv. Acessed 29 May 2020.

14. Araújo ALO, Silva EH, Hernández DG. O contexto pósdemarcatório: quando se trata de redefinir o controle social sobre os recursos naturais e bens culturais. Espaço Ameríndio. 2019;13(1):218-52.

15. Rocha AS, Silva E. XUKURU-KARIRI: mobilidades espaciais indígenas em Alagoas na segunda metade do século XX. Revista Espacialidades. 2019;2(15):115-32.

16. Monteiro GFA, Yeung LL, Caleman SMQ, et al. Indigenous land demarcation conflicts in Brazil: has the supreme Court's decision brought (in)stability? Eur J Law Econ. 2019;48:267-90. https://doi. org/10.1007/s10657-019-09628-3.

17. Sposito F. Nem cidadãos, nem brasileiros: Indígenas na formação do Estado nacional brasileiro e conflitos na Província de São Paulo (1822-1845). São Paulo: Alameda; 2012.

18. Sullivan, L. Identity, Territory and Land Conflict in Brazil Development and Change 2013. https://doi.org/10.1111/dech. 12010

19. Langer PP, Cemin V. Conflitos étnicos no Oeste de Santa Catarina: diáspora e reagrupamento no Araça'í. Cadernos do CEOM. 2003;17(18):243-60.

20. Silva JBS, Laroque LFS. The history of Kaigang people from Linha Glória indigenous land, Estrela, Rio Grande do Sul/Brazil: senses of their (re)territoriality. Soc nat. 2012;24(3):435-47.

21. Moura C. Os quilombos e a rebelião negra. São Paulo: Brasiliense; 1981.

22. Moura C. Quilombos, resistência ao escravismo. São Paulo: Editora Ática; 1987.

23. Leite IB. The Brazilian quilombo: 'race', community and land in space and time. J Peasant Stud. 2015;42:1225-40. https://doi.org/ 10.1080/03066150.2015.1016919.

24. IBGE. Instituto Brasileiro de Geografia e Estatística. Características Étnico-raciais da População: um estudo das categorias de classificação de cor ou raça. Rio de Janeiro: IBGE; 2008.

25. Schwarcz LM. O espetáculo das raças: cientistas, instituições e questão racial no Brasil, 1870-1930. São Paulo: Cia. das Letras; 1993.

26. Schwarcz LM. The spectacle of the races: scientists, institutions, and the race question in Brazil, 1870-1930. New York: Hill and Wang; 1999.

27. Brazilian Institute of Geography and Statistics. Census data. 2010. Available from https://sidra.ibge.gov.br/tabela/3175. Accessed 25 May 2020. 
28. Brazilian Institute of Geography and Statistics. Digital Atlas. 2010. Available from https://censo2010.ibge.gov.br. Accessed 25 May 2020.

29. Mariani D et al. O que o mapa racial do Brasil revela sobre a segregação no país. Nexo Jornal, 2019. Available from https:// www.nexojornal.com.br/especial/2015/12/16/O-que-o-maparacial-do-Brasil-revela-sobre-a-segregação-no-país $>$. Accessed 31 May 2020

30. Paim J, Travassos C, Almeida C, Bahia L, Macinko J. The Brazilian health system: history, advances, and challenges. Lancet. 2011;377(9779): 1778-97.

31. Ayres JCRM, et al. O conceito de vulnerabilidade e as práticas de saúde: novas perspectivas e desafios. In: Czeresnia D, FReitas CM, editors. Promoção da saúde: conceitos, reflexões, tendências. Rio de Janeiro: Fiocruz; 2003. p. 117-40.

32. Ayres JCRM. Interview with José Ricardo Ayres. Saúde Soc São Paulo. 2018;27(1):51-60.

33. Jones CP. Levels of racism: a theoretic framework and a gardener's tale. Am J Public Health. 2000;90(8):1212-5.

34. Atun R, de Andrade LOM, Almeida G, Cotlear D, Dmytraczenko T, Frenz P, et al. Health-system reform and universal health coverage in Latin America. Lancet. 2015;385(9974):1230-47.

35. Alves JAL. A conferência de Durban contra o Racismo e a responsabilidade de todos. Revista Brasileira de Política Int. 2002;45(2):198-223.

36. Werneck J. Institutional racism and black population health. Saude Soc. 2016;25(3):535-49.

37. Freitas DA, Caballero AD, Marques AS, Hernánde CIV, Antune SLNO. Saúde e Comunidades Quilombolas: uma revisão da literatura. Rev CEFAC. 2011;13(5):937-43.

38. Pompeu A União é condenada a R\$ 1 mi por não ouvir indígenas para nomear chefe de saúde. Revista Consultor Jurídico Available from https://www.conjur.com.br/2019-mar-31/uniao-condenadanao-ouvir-indios-nomear-chefe-saude. Accessed 29 May 2020.

39. Boaretto JD, Molena-Fernandes CA, Pimentel GGA. The nutritional status of Kaingang and Guarani Indigenous peoples in the State of Paraná. Brazil Cien Saude Colet. 2015;20(8):2323-8.

40. Anderson I, Robson B, Connolly M, al-Yaman F, Bjertness E, King A, et al. Indigenous and tribal peoples' health (The Lancet-Lowitja Institute Global Collaboration): a population study. Lancet. 2016;388:131-57.

41. Bidinotto AB, D'Avila OP, Martins AB, Hugo FN, Neutzling MB, Bairros FS, et al. Oral health self-perception in Quilombola communities in Rio Grande Do Sul: a cross-sectional exploratory study. Rev Bras Epidemiol. 2017;20(1):91-101.

42. Wanzinack C, Signorelli MC, Shimakura S, Pereira PPG, Polidoro M, Oliveira LB, et al. Indigenous homicide in Brazil: geospatial mapping and secondary data analysis (2010 to 2014). Ciênc saúde colet. 2019;24(7):2637-48.

43. Alves R, Faerstein E. Educational inequalities in hypertension: complex patterns in intersections with gender and race in Brazil. Int J Equity Health. 2016;15:146.

44. Munanga K. Políticas de ação afirmativa em benefício da população negra no Brasil: um ponto de vista em defesa de cotas. Soc e Cult. 2001;4(2):31-43.

45. Htun M. "Racial democracy" to affirmative action: changing state policy on race in Brazil. Lat Am Res Rev. 2004;39(1):60-89.

46. Brasil. Fundação Nacional de Saúde. Política nacional de atenção à saúde dos povos indígenas. $2^{\mathrm{a}}$ Ed. Brasília: Fundação Nacional de Saúde/Ministério da Saúde; 2002.

47. Brasil. Distritos Sanitários Especiais Indígenas (DSEIs). Available from https://www.saude.gov.br/secretarias-estaduais/685institucional/secretarias/secretaria-especial-de-saude-indigenasesai/46396-distritos-sanitarios-especiais-indigenas-dseis. Accessed 26 May 2020
48. Sousa MC, Scatena JHG, Santos RV. O Sistema de Informação da Atenção à Saúde Indígena (SIASI): criação, estrutura e funcionamento. Cad Saúde Pública. 2007;4:853-61.

49. Flaeschen H, Reis V. Ana Lúcia Pontes: "Nos preocupa a garantia da saúde aos indígenas" ["We are concerned about guaranteeing health to indigenous people”]. Brazilian Association of Public Health 2020. Available from https://www.abrasco.org.br/site/ noticias/saude-da-populacao/ana-lucia-pontes-ao-el-pais-nospreocupa-a-garantia-da-assistencia-de-saude-aos-indigenas/41387/. Accessed 21 June 2020.

50. Reis JG, Harzheim E, Nachif MCA, Freitas JC, Davila OP, Hauser L, et al. Criação da Secretaria de Atenção Primária à Saúde e suas implicações para o SUS. Ciência \& Saúde Coletiva. 2019;9:345762.

51. Jucá B Decreto de Bolsonaro com mudanças na saúde indígena dispara alerta no movimento indigenista. El País, 31 June 2019. Available from https://brasil.elpais.com/brasil/2019/05/30/politica/ 1559238132 162541.html. Accessed 20 May 2020.

52. Brasil. Ministério da Saúde. Política Nacional de Saúde Integral da População Negra. Brasília: Editora do Ministério da Saúde; 2007.

53. Brasil. Ministério da Saúde. Política Nacional de Saúde Integral das Populações do Campo e da Floresta. Brasília: Editora do Ministério da Saúde; 2013.

54. ESRI - Environmental Systems Research Institute Software. Spatial Autocorrelation (Global Moran's I) (Spatial Statistics). Available from https://pro.arcgis.com/en/pro-app/tool-reference/spatialstatistics/spatial-autocorrelation.htm. Accessed 20 May 2020.

55. Polidoro M, Canavese D. Porto Alegre's sociopolitical urbanism and neoliberal economic dynamics: perspectives from a local community in the Afro-Brazilian periphery. Local Econ. 2017;32(7): 727-43.

56. Raupp L, Fávaro TR, Cunha GM, Santo RV. Condições de saneamento e desigualdades de cor/raça no Brasil urbano: uma análise com foco na população indígena com base no Censo Demográfico de 2010. Rev Bras Epidemiol. 2017;1:1-15.

57. Brasil. Ministério da Saúde. Estudo medirá propagação do coronavírus em cidades brasileiras. Available from https://www. saude.gov.br/noticias/agencia-saude/46889-estudo-medirapropagacao-do-coronavirus-em-cidades-brasileiras. Accessed 1 June 2020.

58. United Nations. COVID-19 and indigenous peoples. Available from https://www.un.org/ development/desa/indigenouspeoples/ covid-19.html. Accessed 30 May 2020.

59. Harman K, Verma A, Cook J, Radia T, Zuckerman M, Deep A, Dhawan A, Gupta A Ethnicity and COVID-19 in children with comorbidities. Lancet Child Adolesc Health. Published onlibe May 28, 2020. Available from 10.1016/S2352-4642(20)30167-X. Accessed from 2 June 2020.

60. Szfler EMAS. COVID-19 and the impact of social determinants of health. The Lancet. Correspondence. Published online May 18, 2020. Available from https://doi.org/10.1016/S2213-2600(20) 30234-4. Accessed from 2 June 2020.

61. Kirby T Evidence mounts on the disproportionate effect of COVID19 on ethnic minorities. The Lancet. Published online May 8, 2020. Available from https://doi.org/10.1016/S1473-3099(20)30378-9. Accessed from 2 June 2020.

62. Sá MR. The "white plague" on slave ships: smallpox epidemics in colonial Amazonia and the first efforts at immunization. Rev Latinoam Psicopatol Fundam. 2008;11(4):818-26.

63. Chamdouleyron R, Barbosa BC, Bombardi FA, Sousa CR. "Formidável contágio": epidemias, trabalho e recrutamento na Amazônia colonial (1660-1750). Hist Cienc Saude-Manguinhos. 2011;18(4):987-1004.

64. Mbembé J, Meintjes L. Necropolitics. Publ Cult. 2003;15:11-40.

65. Braz RM, Oliveira PTR, Reis AT, Machado NMS. Avaliação da completude da variável raça/cor nos sistemas nacionais de 
informação em saúde para aferição da equidade étnico-racial em indicadores usados pelo Índice de Desempenho do Sistema Único de Saúde. Saúde em Debate. 2013;37(99):554-62.

66. Valente R A morte invisível de quilombolas pela Covid-19. Available from https://https://noticias.uol.com.br/colunas/rubensvalente/2020/04/25/coronavirus-quilombolas-brasil.htm. Accessed from 30 May 2020.

67. COVID-19 in Brazil: "So what?". The Lancet. 2020. Editorial. Published online May 09, 2020. Available from https://doi.org/10. 1016/S0140-6736(20)31095-3. Accessed from 9 May 2020.

68. ACP - Ação Civil Pública n. 0101298-70.2017.4.02.5101. 26 ${ }^{\mathrm{a}}$ Vara da Seção Judiciária do Rio de Janeiro. Sentença (tipo A). Ministério Público Federal. 2017. Available from https://trf-2. jusbrasil.com.br/jurisprudencia/843915495/apelacao-ac1012987020174025101-rj-0101298-7020174025101/inteiro-teor843915526?ref=serp. Accessed from 9 May 2020.

69. Malta M, Rimoind AW, Hoffd NA, Strathdeee SA. The 2019$\mathrm{nCoV}$ pandemic in the global south: A Tsunami ahead. EClinicalMedicine. 2020. Published online. Available from https://doi.org/10.1016/j.eclinm.2020.100384. Accessed from 2 June 2020.

Publisher's Note Springer Nature remains neutral with regard to jurisdictional claims in published maps and institutional affiliations. 